\title{
How the EU supports the Bush doctrine
}

\author{
Benjamin Zyla
}

\begin{abstract}
Soon after the terrorist attacks on September 11th, the Bush administration announced a new national security strategy. Soon thereafter, this strategic document was denounced in European capitals as 'cowboyesk' and isolationist. Particular dislike was announced about the strategy of pre-emption in domestic affairs of other states. Under this plan Washington reserved the right to send U.S. soldiers abroad to intervene in countries before they can pose a threat to the United States. In addition, many officials in Europe rejected Washington's assertion of withdrawing from its membership in the international criminal court, the Comprehensive Test Ban Treaty, and the Kyoto Protocol; it was perceived as a unilateralist foreign policy that rejects America's responsibility in the world. However, what some analysts and commentators neglect to see is that the Bush doctrine also shows elements of Wilsonianism, a policy named after former U.S.

President Woodrow Wilson who stood for promoting democracy, human rights, freedom and effective in international affairs. The European Union published their first security strategy a year after the U.S. published theirs. Interestingly, Brussels advocated similar strategies and concepts to the US strategy. Similarities can be see in both strategies in their messianic approach to create a better world and promote more international oder. This paper argues that despite the unilateralist tone of the current U.S. national security policy, the European strategy and its American counterpart share the same values of how to conduct and what to achieve in international affairs. Consequently, the two strategies can be seen as complementary to each other, not contradictory. The paper will first address the nature of the U.S. national security strategy before analyzing the European security strategy while making reference, in both cases, to the Wilsonian tradition of international affairs.
\end{abstract}




\section{Introduction}

Soon after the terrorist attacks on September $11^{\text {th }}$, the George W. Bush administration announced a new national security strategy. ${ }^{1}$ Shortly thereafter, the document was denounced in European capitals as 'cowboyesk' and isolationist. Particular dislike amongst some European governments was publicized about the strategy of pre-emption in domestic affairs of other states and the notion that Washington reserved the right to send U.S. soldiers abroad to intervene in sovereign countries. In addition, many government officials in Europe rejected Washington's assertion of withdrawing its membership of the International Criminal Court, the Comprehensive Test Ban Treaty, and the Kyoto Protocol - it was perceived by them as a unilateralist foreign policy that rejects America's responsibility in the world. As a result, some analysts on both sides of the Atlantic have suggested that the United States and its European allies are drifting apart due to diverting strategic cultures. ${ }^{2}$ Robert Kagan, for example, argues that the United States acts like an international policeman that unilaterally enforces international order and stability. The U.S. is willing to use its military powers to achieve political objectives whereas the Europeans are portrayed as a civilian power and less inclined to use military forces. ${ }^{3}$

\footnotetext{
${ }^{1}$ In accordance with Goldwater- Nichols Department of Defence Reorganization Act of 1986, every President of the United States has to send a detailed report to Congress outlining the administration's security strategy. See European Council, "A Secure Europe in a Better World: European Security Strategy," (Brussels: European Council, 2003).

${ }^{2}$ For a comparison of the European vs. American security strategy see Felix S. Berenskoetter, "Mapping the Mind Gap: A Comparison of Us and European Strategies," Security Dialogue 36, no. 1 (2005), Simon Duke, "The European Security Strategy in a Comparative Framework: Does It Make for Secure Alliances in a Better World?," European Foreign Affairs Review 9 (2004), Robert Kagan, Paradise and Power: America and Europe in the New World Order (London, New York: Atlantic Books; Alfred A. Knopf, 2003), Robert Kagan, "Power and Weakness," Policy Review 113 (2002).

${ }^{3}$ For the concept of ‘civilian power' see for example Sebastian Harnisch and Hanns Maull, Germany as a Civilian Power?: The Foreign Policy of the Berlin Republic, Issues in German Politics (Manchester; New York: Manchester University Press, 2001), Horst Mendershausen, Civilian Power Europe (Santa Monica, Calif.: Rand Corp., 1975), Mario Telò, Europe, a Civilian Power? : European Union, Global Governance, World Order (Houndmills, Basingstoke, Hampshire ; New York: Palgrave Macmillan, 2006), Henning Tewes, Germany, Civilian Power, and the New Europe: Enlarging Nato and the European Union, New Perspectives in German Studies (Houndmills, Basingstoke, Hampshire ; New York: Palgrave, 2002), Richard Whitman, From Civilian Power to Superpower? : The International Identity of the European Union (Houndmills, Basingstoke, Hampshire, New York: Macmillan Press; St. Martin's Press, 1998).
} 
Review of European and Russian Affairs vol. 2 issue 2 August-September 2006 @ RERA 2006 all rights reserved

However, what analysts and commentators neglect to see is that the Bush doctrine also shows elements of Wilsonianism, a policy named after former U.S. President Woodrow Wilson. Wilson is associated with the idea of promoting democracy, human rights, freedom and the rule of law in international affairs. ${ }^{4}$ The former President believed in the "the principles of liberty" 5 and the responsibility to protect these liberties. The same elements of Wilsonianism can also be found in Europe's first security strategy. About a year after the U.S. published a new national security strategy (NSS), the European Union released its own strategic document partly in response to the NSS and the changing security environment after 9/11. This document constitutes the first official E.U. strategy that is dedicated to formulating a common security strategy for the member states. Interestingly, however, is that Europe's first security strategy is similar to its U.S. counterpart in its Wilsonian ambition of spreading democracy and the rule of law around the world. Both strategies are alike in their messianic approach to create a better world and to enhance global order.

The comparison of the two strategies is an important mental exercise that allows to examine the "transatlantic rhetoric" that took place on both sides of the Atlantic during the debate of the war in Iraq. ${ }^{6}$ This exercise also provides a new perspective to the debate of a 'transatlantic drift' and makes the case that in fact the two continents share very similar strategic objectives. The comparison can also be seen as a basis for a renewed strategic dialogue between the U.S. and the E.U. ${ }^{7}$ The central argument of the article is that the two strategies can be seen as

\footnotetext{
${ }^{4}$ For a greater discussion of traditions of American foreign policy see Walter A. McDougall, Promised Land, Crusader State: The American Encounter with the World since 1776 (Boston: Houghton Mifflin, 1997), Walter Russell Mead, Special Providence: American Foreign Policy and How It Changed the World, 1st ed. (New York: Knopf, 2001).

${ }^{5}$ White House, "The National Security Strategy of the United States of America," (Washington, D.C.: White House, 2002), 3.

${ }^{6}$ Elisabeth Pond succinctly describes in detail the incidents that led to the transatlantic drift. See Elizabeth Pond, Friendly Fire: The near-Death of the Transatlantic Alliance, Eusa's-U.S.-Eu Relations Project Series (Pittsburgh, PA: European Union Studies Association, 2004).

7 This, however, seems to be the hope of the German Government. See Auswärtiges Amt: EU-Sicherheits-Strategie (ESS), Stand: Dezember 2003, abrufbar unter: http://www.auswaertiges-amt.de/www/de/eupolitik/
} 
Review of European and Russian Affairs vol. 2 issue 2 August-September 2006 @ RERA 2006 all rights reserved

complementary to each other and not contradictory. Furthermore, it will be argued that despite the unilateralist tone of current U.S. national security policy, the European security strategy and its American counterpart share similar Wilsonian values of how to achieve greater global order. Hence, the theoretical lines of conflict between the transatlantic alliance partners should be minimal. In order to support the central argument, the paper will be structured into the following sections: it will first address the nature of the U.S. national security strategy and the factors that led to its publication. Then, in a second step, the European security strategy will be examined while making reference, in both cases, to the Wilsonian tradition of international affairs.

\section{The road to the Bush doctrine}

In 1999, Condoleezza Rice published an article in Foreign Affairs outlining Bush's vision of a new foreign policy. ${ }^{8}$ At that time she was special advisor to the then Presidential Candidate George W. Bush and asserted that if he was elected President, his foreign policy would be "more realist” - American foreign policy would be based more on the U.S. national interests. The new Bush administration, Rice argued, would ensure that the American military is capable of deterring war, projecting power as well as renewing America's alliances. ${ }^{9}$ She accused the previous Clinton administration of deploying American troops and risking the lives of U.S. soldiers in countries such as Somalia or Rwanda where the United States had no national interest to be involved in. Then Presidential Candidate, George W. Bush, specified this new foreign policy vision and advocated a “distinctly American internationalism.”10

\footnotetext{
gasp/ess_html [12. März 2004].

${ }^{8}$ Condoleezza Rice, "Promoting the National Interest," Foreign Affairs 79 (January/February 2000): 57.

${ }^{9}$ Ibid.: 47.

${ }^{10}$ George W. Bush, “A distinctly American internationalism,” delivered at the Ronal Reagan Presidential Library, Nov. 19 ${ }^{\text {th }}$, 1999, available at http://www.georgewbush.com/speeches/foreignpolicy/foreignpolicy.asp, accessed Jan. $1^{\text {st }}$, 2006. See also Philip H. Gordon and Jeremy Shapiro, Allies at War: America, Europe, and the Crisis over Iraq (New York: McGraw-Hill, 2004), 48.
} 
Review of European and Russian Affairs vol. 2 issue 2 August-September 2006 C RERA 2006 all rights reserved

At the beginning of his presidency Bush’s ‘distinct foreign policy’, one can argue, was deeply rooted in the neorealist tradition of international relations, which assumes that states are the principal actors in foreign policy. Domestic politics of sovereign states are not relevant in the international power play. Secondly, neorealists assume that the power of the state is essential in the conduct of foreign policy. National interests of states are pursued by resources of power politics. ${ }^{11}$ Inherent in this assumption is the logic that once states gain power it is their desire to expand territorially. ${ }^{12}$ Thirdly, neorealists focus on great power politics and argue that no great power should ever be able to dominate international relations. The balance of power is the key mechanism for the conduct of international affairs. Finally, governments should oppose involvements in internal affairs of sovereign states, humanitarian interventions, and the involvement with international institutions. ${ }^{13}$

Yet, after being sworn into office, the Bush administration continued to have a 'unipolar' world view ${ }^{14}$ in which no other great power would be able to challenge the global hegemon - and primacy was the pre-eminent strategy. ${ }^{15}$ The NSS acknowledges that the "United States possesses unprecedented - and unequalled - strength and influence in the world."16 As a result of this new unilateralist foreign policy, the administration rejected the Kyoto Protocol to control global

\footnotetext{
${ }^{11}$ Fareed Zakaria, From Wealth to Power: The Unusual Origins of America's World Role, Princeton Studies in International History and Politics (Princeton, N.J.: Princeton University Press, 1998), 8-9.

12 James M. McCormick, American Foreign Policy and Process, 4th ed. (Belmont, CA: Thomson/Wadsworth, 2005), 210.

${ }^{13}$ Ibid, p. 212.

${ }^{14}$ Charles Krauthammer called it the 'unipolar moment'. See Charles Krauthammer, "The Unipolar Moment," Foreign Affairs 70 (1990/1991).

15 The focus of the grand strategy of primacy lies on great power relations in an anarchic world. It is a classical realist theory. The primary objective of this grand strategy is that a state wants to keep its supremacy over other competitive states that intend to reach a great power status. Secondly, a strategy of primacy is motivated by both power and peace. It tries to ensure peace in the world, and it is its view that only a preponderance of U.S. power ensures peace and stability in the world. "Peace is the result of an imbalance of power in which U.S. capabilities are sufficient, operating on their own, to cow all potential challengers and to comfort all coalition partners". This strategic view clearly demands a unipolar environment; multipolarity is not permitted and not desired. See Barry R. Posen and Andrew Ross, "Competing Visions of U.S. Grand Strategy," International Security 21, no. 3 (winter 1996/97): 32.

${ }^{16}$ See the 2002 and 2006 National Security Strategy: White House, The National Security Strategy of the United States of America (Washington, D.C.: White House, 2002), White House, "The National Security Strategy of the United States of America," (Washington, D.C.: White House, 2006).
} 
warming, disagreed with the Comprehensive Test Ban Treaty (CTBT) that limits the spread of nuclear weapons, and withdrew from the 1972 Anti Ballistic Missile Treaty (ABM). It also rejected its membership of the International Criminal Court. What was apparent was that the United States was deemed to reduce the amount of 'entangling alliances ${ }^{17}$ that would impede on American sovereignty.

However, the terrorist attacks on September 11th transformed the nature of U.S. foreign policy and shifted into a more defensive realist mode mixed with elements of idealism. Defensive realism basically shares the same assumptions as do classical realists. However, the major difference between the two is that defensive realism highlights the importance of a state's insecurity, which is the driving motivation for a state to act militarily for its own defence. ${ }^{18}$ Since states can never be certain of other states' present or future intentions they are seeking policies vis-à-vis potential adversaries. The President's foreign policy shifted from a narrow definition of American national interests to include a broader set of values and principles. ${ }^{19}$

Lastly, idealist views and attitudes were embodied into U.S. foreign policy advocating for regime change and the promotion of democracy and freedom around the world. ${ }^{20}$ In short, the previous “distinct American internationalism” was modified to a "comprehensive American globalism”.

\footnotetext{
${ }^{17}$ The notion of 'entangling alliances' stated that America should remain independent from its European heritage, Britain and France in particular. It was first used by George Washington in his farewell address. This address was written primarily to eliminate himself as a candidate for a third term. It was never read by the President in public, but it was printed in Claypoole's American Daily Advertiser, Philadelphia, September 19, 1796. The doctrine stated that the United States should stay out of European conflicts to avoid an engagement into alliances with European powers that would impede on U.S. room of manoeuvre. See McDougall, Promised Land, Crusader State: The American Encounter with the World since 1776.

${ }^{18}$ Zakaria, From Wealth to Power: The Unusual Origins of America's World Role, 8-10.

${ }^{19}$ McCormick, American Foreign Policy and Process, 219.

${ }^{20}$ Idealists believe strongly in the affective power of ideas, in that it is possible to base a political system primarily on morality. The idealist school of thought is the oldest school of international relations. The theory of idealism has its origins in the First World War when the widespread view was the military force cannot achieve the objective of keeping the peace. See Martin Hollis and Steve Smith, Explaining and Understanding International Relations (Oxford, New York: Clarendon Press; Oxford University Press, 1990), 16-20.
} 
Review of European and Russian Affairs vol. 2 issue 2 August-September 2006 @ RERA 2006 all rights reserved

\section{The Bush doctrine}

The National Security Strategy (NSS) of September 20, 2002 outlined strategies and tactics on how to best meet the threats facing the United States in the $21^{\text {st }}$ century. The President himself conveyed his visions of a new U.S. defence strategy in the State of the Union address on January 29, 2002, saying that "we must prevent the terrorists and regimes who seek chemical, biological, or nuclear weapons from threatening the United States and the world”. ${ }^{21}$ In the following months, Iran, Iraq, and North Korea were labelled as the "axes of evil”, a list of countries that pose a threat to America. President Bush explained his strategic vision, which became better known as the Bush doctrine, in a speech at West Point on June 1, 2002 in greater detail:

For much of the last century, America's defence relied on the Cold War doctrines of deterrence and containment. In some cases, those strategies still apply. But new threats also require new thinking. Deterrence -- the promise of massive retaliation against nations -- means nothing against shadowy terrorist networks with no nation or citizens to defend. Containment is not possible when unbalanced dictators with weapons of mass destruction can deliver those weapons on missiles or secretly provide them to terrorist allies. We cannot defend America and our friends by hoping for the best. We cannot put our faith in the word of tyrants, who solemnly sign non-proliferation treaties, and then systemically break them. If we wait for threats to fully materialize, we will have waited too long. ${ }^{22}$

The Bush doctrine has four main characteristics. First, the administration in Washington recognizes that domestic regimes of certain states constitute a vital threat to the United States. This assertion is consistent with Waltz's second image of the causes of war. ${ }^{23}$ It describes the internal character of the state - public beliefs and practices, opinions and expectations, political systems and institutions of government that can affect the interaction between states. Consequently, the only strategic option is to pursue regime change in those countries that pose a threat to the U.S. The second characteristic of the Bush doctrine is the notion of pre-emptive and

\footnotetext{
${ }^{21}$ http://www.whitehouse.gov/news/releases/2003/01/20030128-19.html, accessed Jan. $19^{\text {th }}$, 2005.

${ }^{22} \mathrm{http}: / /$ www.whitehouse.gov/news/releases/2002/06/20020601-3.html, accessed Jan. $21^{\text {st }}, 2005$.

${ }^{23}$ See Kenneth Neal Waltz, Man, the State, and War; a Theoretical Analysis (New York,: Columbia University Press, 1959).
} 
Review of European and Russian Affairs vol. 2 issue 2 August-September 2006 @ RERA 2006 all rights reserved

preventative use of military force. The President reserves the right of anticipatory military actions against any state that poses a threat to America's national security. International law and alliances are no longer the guiding principles of international diplomacy and are being replaced by ‘coalitions of the willing', which offer Washington more strategic and tactical flexibility. These new coalitions also highlight an instrumentalist view of international organizations: they are only consulted if they favour U.S. policies and agendas. Thirdly, the doctrine asserts that peace and stability in the world require U.S. primacy. The 'unipolar moment' ${ }^{24}$, as Charles Krauthammer coined it, should be extended. The United States seeks to dominate international affairs for some time to come. Lastly, the new national security strategy speaks highly in favour of the spread of democracy and free markets around the globe. This is a classical Wilsonian element of U.S. foreign policy and highlights the belief that enhancing globalized trade and freedom will raise living standards for everybody.

\section{Wilsonianism and the Bush doctrine}

Woodrow Wilson was the first U.S. president that was confronted with the new revolutions of the twentieth century. 'Wilsonian' became a label for a style of U.S. foreign policy that is committed to internationalism and moralism in world politics that were dedicated to extending democracies. However, critics and proponents of 'Wilsoniansm' are united in the view that the former president indeed had the largest long term vision of the nation's future. ${ }^{25}$ For President Woodrow Wilson the justification for U.S. global engagements was messianic and a long-term oriented vision for U.S. foreign policy. He was not only a politician but also a scholar and former president of Princeton University who formed policies out of “an understanding of the nation's

\footnotetext{
${ }^{24}$ Krauthammer, "The Unipolar Moment."

${ }^{25}$ Walter LaFeber, The American Age: United States Foreign Policy at Home and Abroad since 1750, 2nd ed., 2 vols. (New York: Norton, 1994), 269.
} 
history."26 The United States, Wilson thought, has an obligation to spread the principles and values of the United States around the world. However, these unique Wilsonian characteristics were shaping American foreign policy long before he became president. They are, as Walter R. Mead argues, "deeply rooted in the national character" of the United States and have been a consistency in American foreign policy for a long time. ${ }^{27}$ Wilson himself outlined the principles in his fourteen point speech in an address to a Joint Session of Congress on January 8, 1918. ${ }^{28}$ The United States, he argued, is an exceptional nation that rejects great power politics and is proud of its democratic institutions. International order, in Wilsonian terms, is based on universal law, national trust and freedom. He saw the United States as a model the world should follow. The belief of a global civil society is rooted in the American missionary movement in which American religious groups alleged that the Western world has a duty to support the development of what is today called the third world. ${ }^{29}$ "The missionary movement indeed deserves far more credit for promoting the idea of a global human community than it often receives.”30

Yet, Wilson insisted that the U.S. has the right and moral duty to "change the rest of the world's behaviour.”31 A country should not be guided exclusively by its national interest but by its commitment to spread democracy and freedom around the world to ensure a more stable international system. ${ }^{32}$ Wilson himself said: "We are participants, whether we would or not, in

\footnotetext{
${ }^{26}$ Ibid., 270.

${ }^{27}$ Mead, Special Providence: American Foreign Policy and How It Changed the World, 134 and 39.

${ }^{28}$ In the theoretical literature about U.S. foreign policy this event is also seen as the turning point from isolationism towards internationalism and more international engagement. LaFeber argues that Wilson had little choice and that the United States “could no longer withdraw from world affairs.” See LaFeber, The American Age: United States Foreign Policy at Home and Abroad since 1750, 303. Wilson himself stated in his fourteen point speech that "neutrality is no longer feasible or desirable” for the United States. A the first step towards greater international engagement was "to make the world safe for democracy".

${ }^{29}$ See Mead, Special Providence: American Foreign Policy and How It Changed the World, chapter 5 for a greater discussion of these historical roots.

${ }^{30}$ Ibid., 139-51.

${ }^{31}$ Ibid., 138.

32 This became known as the 'democratic peace theory'. For a greater discussion see Michael Mandelbaum, The Ideas That Conquered the World: Peace, Democracy, and Free Markets in the Twenty-First Century, 1st ed. (New York: Public Affairs, 2002).
} 
Review of European and Russian Affairs vol. 2 issue 2 August-September 2006 C RERA 2006 all rights reserved

the life of the world. The interests of all nations are our own also. We are partners with the rest.",33

Elements of the Wilsonian tradition can be found in President Bush's foreign policy. ${ }^{34}$ Afghanistan and later Iraq are the most recent examples where the United States engaged in nation-building, and is trying to promote democratic institutions and the rule of law. ${ }^{35}$ After the terrorist attacks on September $11^{\text {th }}$, Bush's foreign policy shifted towards regime change in the Middle East. The purpose of the war in Afghanistan and later on in Iraq was to transform dictatorial regimes that suppress their people and transform it into prosperous democracies where the state is governed by the rule of law, democracy, and freedom. It is the Wilsonian belief that democracies are better reliable partners than totalitarian regimes. "Democracy guards against one of the most dangerous forms of misrepresentation and misgovernance: the domination of the state by the military elite.”36 A short empirical survey reveals America’s commitment to Wilsonian ideals: the word 'democracy' appears fourteen times in the 2002 document and fifty-two times in the 2006 edition. Further, promoting the rule of law and institutions is mentioned ten times in the 2002 strategy and sixteen times in 2006. The word 'freedom' the 2002 is used forty-six times in 2002 and eighty-one times in the 2006 document.

In addition, economic liberalization and free markets would lead the way to an integration into the global economy and prosperity. The NSS links free trade and development with each other and asserts that "the lessons of history are clear: market economies ... are the best way to promote prosperity and reduce poverty." 37 It is the notion of 'extending freedom' and 'spreading democracy' around the world that is a fundamental, global security imperative for the U.S.

\footnotetext{
${ }^{33}$ Quoted in McDougall, Promised Land, Crusader State: The American Encounter with the World since 1776, 122.

${ }^{34}$ Michael J. Mazzarr, "George W. Bush, Idealist," International Affairs 79, no. 3 (2003).

${ }^{35}$ Francis Fukuyama, Nation-Building: Beyond Afghanistan and Iraq (Baltimore: Johns Hopkins University Press, 2006), Francis Fukuyama, State-Building: Governance and World Order in the 21st Century (Ithaca, N.Y.: Cornell University Press, 2004).

${ }^{36}$ Mead, Special Providence: American Foreign Policy and How It Changed the World, 163.

${ }^{37}$ White House, "The National Security Strategy of the United States of America," 17.
} 
Review of European and Russian Affairs vol. 2 issue 2 August-September 2006 @ RERA 2006 all rights reserved

administration. This, again, appears to be consistent with the Wilsonian tradition of international affairs. Yet, President Bush’s world view is not as messianic and long term oriented as Wilson's'. This might have to do with Wilson's fear of a revolution that would change the United States as it did in Europe. He wanted world order and thus required a long term policy to achieve such order. “The president...wanted that world to be a safe and an orderly place in which Americans could compete equally - perhaps even a place in which all people... would become much like Americans. ${ }^{38}$ Nonetheless, it is American neoconservatives who are prepared to use military power to promote liberal values. A French analyst has called the strategic objective of regime change in combination with promoting liberal values such as democracy, liberty and the rule of law as 'Wilsonianism in boots'. ${ }^{39}$

Moreover, the United States sought to establish market economies that would open highly regulated markets in the Middle East and foster local entrepreneurship. The President's vision was that a healthy economy would be the best source of global stability. This is consistent with the assumptions of the democratic peace theory, which says that liberal democratic states have been able to maintain peaceful relations amongst themselves, but are prone to wage war against non-liberal/democratic regimes. ${ }^{40}$ Other scholars have outlined that three major ideas have characterized the modern world: peace, democracy, and free markets are seen as the optimal ways to organize political life. ${ }^{41}$ "If others make something that you value, you should be able to

\footnotetext{
${ }^{38}$ LaFeber, The American Age: United States Foreign Policy at Home and Abroad since 1750, 272-73.

${ }^{39}$ Pierre Hassner, The United States: The Empire of Force or the Force of Empire?, Chaillot Papers No. 54 (Paris: Institute for Security Studies, European Union, 2002), 43.

${ }^{40}$ For further reference to the democratic peace theory see for example Michael Doyle, "Kant, Liberal Legacies and Foreign Affairs," Philosophy and Public Affairs 12, no. 4 (1985), Michael Doyle, "Kant, Liberal Legacies and Foreign Affairs - Part 1," Philosophy and Public Affairs 12, no. 3 (1985), Michael Doyle, "Kant, Liberal Legacies, and Foreign Affairs," in Debating the Democratic Peace, ed. Sean Lynn-Jones and Michael Brown (Cambridge: MIT, 1996), Mandelbaum, The Ideas That Conquered the World: Peace, Democracy, and Free Markets in the Twenty-First Century. See also Mazzarr, "George W. Bush, Idealist."

${ }^{41}$ Mandelbaum, The Ideas That Conquered the World: Peace, Democracy, and Free Markets in the Twenty-First Century, 62.
} 
Review of European and Russian Affairs vol. 2 issue 2 August-September 2006 @ RERA 2006 all rights reserved

buy it. This is real freedom, the freedom for a person - or nation- to make a living." ${ }^{42}$ President Bush believes that free trade in the Middle East as well as free markets around the globe will create more employment opportunities and higher income for the region. This economic growth would also raise educational standards and employment for their citizens. Expected tax revenue from higher employment rates, for example, could be used to invest into infrastructure, institutions, law enforcement institutions, and a better health care system.

Afghanistan was a perfect example of a poor country that was devastated by civil wars and foreign interventions throughout its history. The gross domestic product of the economy per capita was about $\$ 150$ in 2004 . It drove many Afghans to leave their country to live and work across the border in Pakistan where the living conditions were much friendlier. Overall, several million Afghan people were dependent on food shipments from abroad. To help the Afghan people, the U.S. committed $\$ 4.5$ billion dollars over five years for rebuilding the country. This Wilsonian element of the Bush doctrine was sought to be applied as a universal formula in every part of the world. It had strategic as well as moral origins. Strategically, poverty, crime and corruption could pose a threat to American national security. Poor nations might fall into the hands of terrorists. Morally, poverty in the world affected American values: “A world where some live in comfort and plenty, while half of the human race lives on less than $\$ 2$ a day, is neither just nor stable."43 The core objective of the U.S. administration was to give Afghans the opportunity to make the same choices as Americans made two hundred years ago - they chose democracy, freedom, and free enterprise. "The United States will use its moment of opportunity to extend the benefits of freedom across the globe. We will actively work to bring the hope of

\footnotetext{
${ }^{42}$ The National Security Strategy of the United States, 18.

${ }^{43}$ Idid, p. 21. 
Review of European and Russian Affairs vol. 2 issue 2 August-September 2006 C RERA 2006 all rights reserved

democracy, development, free markets, and free trade to every corner of the world." ${ }^{\text {44 }}$ However, contrary to Wilson, it was short term oriented.

Yet, it is not only the promotion of democracy and free trade that makes the current Bush doctrine inherently Wilsonian, but also its commitment to multilateralism. “This is a missionary, idealist administration in the best ... traditions of Wilsonianism." ${ }^{45}$ Current wars in Iraq and Afghanistan require a high degree of international collaboration and cooperation. The international community, including the European Union, supported the United States in the war against terrorism by sharing vital intelligence information and providing logistical support in order to prevent a further destabilization of the region. Germany, for example, as one of the countries that opposed the war in Iraq, allowed the United States over flight rights, and shared crucial intelligence information of two of their officers in Bagdad with the CIA. ${ }^{46}$ It also trains Iraqi police forces outside of Iraq and provides other logistical support. Intelligence agencies on both continents tracked international terrorists and money laundering regimes, and froze suspicious bank accounts of terrorists and their organizations. In short, this is the multilateral element of the Bush doctrine. ${ }^{47}$ Yet, it is an instrumentalist foreign policy that makes use of its alliances and international organizations when they are congruent with American national interests.

\section{Europe and the question of power and security}

The European Union published its security strategy (ESS) in December 2003 in which it outlines how to cope with external threats such as terrorism and weapons of mass destruction. "It

\footnotetext{
${ }^{44}$ Ibid.

${ }^{45}$ Mazzarr, "George W. Bush, Idealist," 509.

${ }^{46}$ See Dominik Cziesche and Holger Stark, "Aktion Glasnost: Ein Bericht Des Kanzleramts Legt Details Der Operationen Deutscher Sicherheitsbehörden Offen - Die Regierungskoalition Sieht Die Dienste Entlastet," DER SPIEGEL 9/2006, Michael R. Gordon, "German Intelligence Gave U.S. Iraqi Defense Plan," The New York Times, February 272006.

${ }^{47}$ Stephen M. Walt, Taming American Power: The Global Response to U.S. Primacy, 1st ed. (New York: Norton, 2005).
} 
Review of European and Russian Affairs vol. 2 issue 2 August-September 2006 C RERA 2006 all rights reserved

sets out an analysis of and response to the most salient security threats the Union is facing." ${ }^{48}$ It is guided by the decisions made by the European Council's meeting in Cologne in 1999 that laid the foundations for early, rapid, and if necessary robust European civilian and military crisis management capabilities. These 'new' capabilities were designed to allow Brussels the deployment of its military forces around the world for conflict prevention missions. They were based on the "Petersberg Tasks"49 - evacuation, humanitarian and rescue missions including humanitarian aid, separation of warring factions, and conflict prevention. It also strengthens the picture of the Union as a global actor in international affairs and highlights the importance its civilian crisis management capabilities such as police, the rule of law, strengthening civilian administrations, negotiation and consultation to engage in these areas. ${ }^{50}$ Yet, under the Helsinki Headline Goal in 1999 a European Rapid Reaction Force (ERRF) of 60.000 troops was created with the mandate to carry out the Petersberg Tasks. ${ }^{51}$ Yet, due to capability shortfalls and lack of commitments in European capitals the headline goals did not fully materialize. Instead, a smaller version of the RRF, the European battle group concept was developed that consists of max. 1.500 troops and is on stand by for short notice deployments.

However, the E.U. security strategy is explicit in saying that European forces will only be deployed in multilateral operations and with the consent of other nations or international organizations. ${ }^{52}$ This shows that the E.U. subscribes to the doctrine of multilateralism in

\footnotetext{
${ }^{48}$ Christoph O. Meyer, "Convergence Towards a European Strategic Culture? A Constructivist Framework for Explaining Changing Norms," European Journal of International Relations 11, no. 4 (2005): 524. See also Sven Biscop, The European Security Strategy: A Global Agenda for a Positive Power (Hants, England: Ashgate, 2005), Alexander Skiba, "Die Nationale Sicherheitsstrategie Der USA Und Die Europäische Sicherheitsstrategie in Vergleich," in Wissenschaft \& Sicherheit: Beiträge zur Sicherheitspolitik - Sonderband (BSR- Arbeitskreise Sicherheitspolitik an Hochschulen, Sonderband 4/2004).

${ }^{49}$ The negotiations were held on a hotel on the Petersberg near Bonn/Germany. The Petersberg Tasks were literally taken from the Western European Union's toolbox

${ }^{50}$ See $2385^{\text {th }}$ European Council meeting, General Affairs, 19-20.XI.2001, Brussels, 19-20 November 2001. Further, the EU defines its global power status by referring to the size of its populations and the percentage of its Gross National Product (GNP).

${ }^{51}$ The European Council in Feira decided to recruit 5000 policemen that are deployable within two months and sustainable for at least one year.

${ }^{52}$ European European Council, "A Secure Europe in a Better World: European Security Strategy," 9.
} 
Review of European and Russian Affairs vol. 2 issue 2 August-September 2006 @ RERA 2006 all rights reserved

international affairs that is based on international cooperation. This commitment is consistent with Wilsonian ideas of conducting international relations. Consequently, it can be argued, the European security strategy is consistent with the NSS in its ambition of making the world not only a safer but also a better place. Both strategies highlight the significance of international terrorism and state failures as threats to international order. "State failure and organized crime spread if they are neglected - as it was seen in West Africa. This implies that we should be ready to act before a crisis occurs.

However, the historical experience of the member states dissuades the Union's willingness to engage in military conflict. The strategy makes explicit reference to the 'European experience' and the lessons learned from two devastating world wars. It bases all E.U. strategic and tactical engagements and commitments on these experiences. These lessons learned and the positive experiences of the process of European integration made Europe democratic, wealthy and peaceful. "Europe has never been so prosperous, so secure nor so free. The violence of the first half of the 20th Century has given way to a period of peace and stability unprecedented in European history." 54 It underlines the unwillingness in European capitals to see the world in terms of power relations and is the source of Europe's commitments to conflict prevention and the promotion of the rule of law. ${ }^{55}$ Stability through cooperation became the leitmotiv of European diplomacy. "Europe seems, therefore, to be a model of non-military power, influential but disinclined to use force."56

However, the E.U. does not shy away from the possibility of deploying military forces at all. The strategic document states that Brussels is willing to send forces abroad as a last resort for

\footnotetext{
${ }^{53}$ Ibid., 7.

54 Ibid.

${ }^{55}$ See Robert Cooper, The Breaking of Nations: Order and Chaos in the Twenty-First Century (New York: Atlantic Monthly Press, 2003).

${ }^{56}$ Ibid., 161.
} 
Review of European and Russian Affairs vol. 2 issue 2 August-September 2006 @ RERA 2006 all rights reserved

solving international conflicts. ${ }^{57}$ Ambassadors of the European Union's Political and Security Committee drafted the first version of the strategy and sold it to the national foreign ministers. It shows that key actors in the ESDP institutional framework were engaged in developing a more pro-active role of the Union in international affairs. What took place in the European Union is what Christoph Meyer called a "normative convergence”,58 of national strategic cultures. Contrary to the accepted wisdom of Europe’s “capability-expectations gap"59, E.U. member states transformed gradually from defensive oriented countries towards more proactive states working towards a more unified European policies. The result is a de-prioritisation of territorial defence, the acceptance of intervention in sovereign states for humanitarian reasons, and an institutionalized set of norms. ${ }^{60}$ Meyer showed that the new ESS represents a departure of NATO’s strategic thinking of more autonomous European military capabilities. ${ }^{61}$ Again, the foundation of Europe's increased military engagement is its experience in the Balkans and its impotence of preventing massacres such as the one in Srebrenica. The blame and shame of the international community to the Union's inability to act started a process of re-thinking traditional security paradigms towards "more reactive and territorial defence-oriented national security cultures and initiated a process of societal learning in a number of member states."62 The new engagement constitutes a "shift away from the 'civil power' leitbild towards a Union that aims to develop autonomy in defence matters and considers the use of military force a legitimate option to tackle security threats." ${ }^{63}$ Nonetheless, there also appears to be a difference between the European and the American security strategy. The European security strategy is 'passively

\footnotetext{
${ }^{57}$ Meyer, "Convergence Towards a European Strategic Culture? A Constructivist Framework for Explaining Changing Norms," 544.

${ }^{58}$ Ibid.: 545.

${ }^{59}$ See for example Christopher Hill, "The Capability-Expectations Gap, or Conceptualizing Europe's International Role," Journal of Common Market Studies 31, no. 3 (1993).

${ }^{60}$ Meyer, "Convergence Towards a European Strategic Culture? A Constructivist Framework for Explaining Changing Norms."

${ }^{61}$ Ibid.: 539.

62 Ibid.: 540.

${ }^{63}$ Ibid.: 539. 
aggressive' in the sense that European policy makers do not subscribe to the U.S. ambition of transforming other countries around the world into prosperous democracies. Instead, other countries approach Brussels and ask for their assistance in the democratization and/or domestic transition processes. Other countries are used as the ‘vehicles’ for Europe’s Wilsonian ambitions. For example, the E.U. implicitly offered the peoples of Eastern Europe a prosperous and democratic future should they overcome communism. Within two years between 1994-96 ten Central and Eastern European states applied for membership in the European Union. Brussels signed a so called association agreements with applicant states and imposed conditions of reform on them. The acquis communautaire laid out the treaties and regulations of the European Union and a roadmap for the applicant countries for transforming their economies, reforming their judicial systems, and preparing their political systems for accountability and democracy.

However, up until today, the E.U. has deployed military forces in various missions in support of its Wilsonian objectives. Under the heading of the European Security and Defence Policy (ESDP), the E.U. has been running ten formal crisis management operations (3 military and 7 civilian). Seven of them are still ongoing (1 military, 5 civil, 1 mixed) in theatres all over the world. ${ }^{64}$ A European Capability Action Plan was launched at the E.U. Council's meeting in Laeken in 2003 to boost the development of European crisis management capabilitiesparticularly in the field of police. One thousand police officers should be ready to for deployment within less than thirty days, two hundred experts in the rule of law, and specialists for civilian administration should be ready to be posted on short notice. The Ministerial Crisis Management Capability Conference, held on 19 November 2002, confirmed the commitments of the member states. In addition, in 1999 the European Council in Helsinki authorized a European Rapid

\footnotetext{
${ }^{64}$ Operation "Concordia” (FYR Macedonia), Operation “Artemis” (Congo), Operation “Althea” (Bosnia Herzegowina), Operation “Amis” (Darfur), Operation "Proxima” (FYR Macedonia), Operation "EU PM” (Bosnia), Operation "EU POL Kinshasa” (Congo), Operation "EU Just Lex" (Middle East), Operation "EU Sec” (Congo), and Operation "EU Just Themis" (Georgia).
} 
Reaction Force composed of 50-60,000 troops that will perform humanitarian and rescue missions, traditional peacekeeping missions, and peacemaking tasks. ${ }^{65}$ These commitments were developed to underline Europe's commitments and efforts in nation-building. However, it is no secret in European capitals that the E.U. is new to the business of peace support operations. ${ }^{66}$

The E.U. security strategy provided the strategic objective of these missions and specified the goals of Europe's global engagements. Altogether, the E.U. developed four areas of civilian crisis management: the rule of law, civil administration, civil protection, and police. In the area of the rule of law, the aim of the Council is to provide 200 agents ready for deployment to assist in establishing law and order in failed or failing societies. Judges, prosecutors, and correctional officers are deployed in support of developing democratic institutions and to ensure rule based democratic transitions. ${ }^{67}$ This could be to reform the public administration of a country, the judicial system, the police, and reform the electoral process. Thirdly, civil protection forces involve European internal protection mechanisms for crisis management. Finally, the area of civil administration is the least developed areas of Europe's four pillars in civilian crisis management.

\section{Wilsonianism and the E.U. security strategy}

By analyzing the Union's strategic document and subsequent decisions of the E.U. Council, it becomes clear that the E.U. is driven by a Wilsonian vision of international relations. First, the E.U. makes clear that international conflicts can only be solved multilaterally. "We need to pursue our objectives both through multilateral cooperation in international organisations and through partnerships with key actors." ${ }^{\text {,6 }}$ Second, the E.U., like the United States, intends to

\footnotetext{
${ }^{65}$ Raimo Väyrynen, "The European Union’s New Crisis Management Capability," (Policy Briefing of the Joan B. Kroc Institute for Peace Studies, February 2000).

${ }^{66}$ Antonio Missiroli, "The European Union: Just a Regional Peacekeeper," European Foreign Affairs Review 8, no. 4 (2003): 493.

${ }_{67}^{67}$ European Security Review, No. 10, January 2000, p. 1.

${ }^{68}$ European Council, "A Secure Europe in a Better World: European Security Strategy," 13. 
export Europe's values to other countries. It recognizes that regional conflicts and failed states are the primary threats to the Union. ${ }^{69}$ Failed states in Afghanistan, for example, may pose a risk to European security in the years to come, especially countries that are close to the European heartland. Issues such as organized crime, human smuggling, democracy, freedom and human rights are already pressing concerns of the Union. In order to better manage these risks, the E.U. strategy advocates an active engagement and investment into nation-building capabilities and the spread of democracy. The European Union and its member states have intervened to help deal with regional conflicts and to put failed states back on their feet, including in the Balkans, Afghanistan, and in the Democratic Republic of Congo (DRC). "Restoring good government to the Balkans, fostering democracy and enabling the authorities there to tackle organised crime is one of the most effective ways of dealing with organised crime within the E.U."70

Furthermore, the strategy clearly espouses the promotion of economic and political interdependence with less fortunate countries. "We need to extend the benefits of economic and political cooperation to our neighbours in the East while tackling political problems there."71 This commitment is consistent with the objectives of the American NSS as well as the 'democratic peace theory'. "We need to extend the benefits of economic and political cooperation to our neighbours in the East while tackling political problems there.”72 Part of Europe’s commitment to stabilizing failed states is its European Development Fund that distributes money to countries of less fortune. It could be accompanied by assistance programs or targeted trade measures. However, to ensure liberalized markets and the respect for human rights and freedoms, it is recognized that the rule of international law, another Wilsonian element in the security strategy, should be respected and extended. Only when the international community respects international

\footnotetext{
${ }^{69}$ Ibid.

${ }^{70}$ Ibid., 6.

${ }^{71}$ Ibid., 8.

${ }^{72}$ Ibid, p.8. 
Review of European and Russian Affairs vol. 2 issue 2 August-September 2006 @ RERA 2006 all rights reserved

law and arbitration, conflicts can be contained and resolved. The E.U. recognizes that the fundamental framework for international relations is the United Nations Charter. The United Nations Security Council has the primary responsibility for the maintenance of international peace and security. In order to strengthen these responsibilities the E.U. is committed to reform the United Nations and its sub-organizations. "We are committed to upholding and developing International Law... Strengthening the United Nations, equipping it to fulfil its responsibilities and to act effectively, is a European priority." ${ }^{73}$ This rule based international order includes the reformation of the World Trade Organization as well as the International Criminal Court.

\section{Conclusion}

This article argued that both the U.S. national security strategy and its European counterpart share similar strategic objectives and are committed to a world order based on Wilsonian values and visions. Thus, it was shown that both documents can be seen as complementary to each other and that both are rooted in the Wilsonian vision of international affair - that is the promotion of democracy, the rule of law, freedom of people, free markets and open access to markets. Further, the conduct of international relations should be based on the rule of international law. It was shown that despite the unilateralist tone in the current U.S. national security strategy and its notion of pre-emption and prevention, its nature is multilateralist.

Yet, there are also dissimilarities. Even though President Bush's 'distinct internationalism' appears to be consistent with the Wilsonian tradition of U.S. foreign policy, it lacks Wilson's long term visions. Instead, the President instrumentalizes American consultation and cooperation with international institutions as long as they favour U.S. policies. For example, in the most recent war on terrorism, the United States shared crucial intelligence information with its allies, particularly those from Europe, but only to the end of gaining vital intelligence

\footnotetext{
${ }^{73}$ European Council. A Secure Europe in a Better World, p.9. 
Review of European and Russian Affairs vol. 2 issue 2 August-September 2006 @ RERA 2006 all rights reserved

information in return. The German government, for example, had two agents posted to Baghdad on the eve of the U.S. bombing campaign and cabled a list of possible targets and other tactical intelligence information to the administration in Washington. ${ }^{74}$

Similar multilateral pledges can be found in the current European security strategy. It outlines clear guidelines how to prevent international crisis. Amongst the advocated policies is the commitment to promote free markets and democracy in failed or failing states, the promotion of the rule of law as well and civilian police commitments. In sum, it should be said that the two security strategies share rather similar visions of a post 9/11 world order. Thus, the transatlantic alliance can be seen as strategically more coherent as Robert Kagan forecasted. Therefore, the transatlantic alliance should have a future to come.

\footnotetext{
${ }^{74}$ The German newsmagazine DER SPIEGEL first broke the story. See footnote 46 for details. 
Review of European and Russian Affairs vol. 2 issue 2 August-September 2006 @ RERA 2006 all rights reserved

\section{Bibliography}

Berenskoetter, Felix S. "Mapping the Mind Gap: A Comparison of Us and European Strategies." Security Dialogue 36, no. 1 (2005): 71-92.

Biscop, Sven. The European Security Strategy: A Global Agenda for a Positive Power. Hants, England: Ashgate, 2005.

Cooper, Robert. The Breaking of Nations: Order and Chaos in the Twenty-First Century. New York: Atlantic Monthly Press, 2003.

Cziesche, Dominik, and Holger Stark. "Aktion Glasnost: Ein Bericht Des Kanzleramts Legt Details Der Operationen Deutscher Sicherheitsbehörden Offen - Die Regierungskoalition Sieht Die Dienste Entlastet." DER SPIEGEL 9/2006.

Doyle, Michael. "Kant, Liberal Legacies and Foreign Affairs." Philosophy and Public Affairs 12, no. 4 (1985): 323-53.

. "Kant, Liberal Legacies and Foreign Affairs - Part 1." Philosophy and Public Affairs 12, no. 3 (1985): 205-35.

. "Kant, Liberal Legacies, and Foreign Affairs." In Debating the Democratic Peace, edited by Sean Lynn-Jones and Michael Brown. Cambridge: MIT, 1996.

Duke, Simon. "The European Security Strategy in a Comparative Framework: Does It Make for Secure Alliances in a Better World?" European Foreign Affairs Review 9 (2004): 459-81.

European Council. "A Secure Europe in a Better World: European Security Strategy." Brussels: European Council, 2003.

Fukuyama, Francis. Nation-Building: Beyond Afghanistan and Iraq. Baltimore: Johns Hopkins University Press, 2006.

- State-Building: Governance and World Order in the 21st Century. Ithaca, N.Y.: Cornell University Press, 2004.

Gordon, Michael R. "German Intelligence Gave U.S. Iraqi Defense Plan." The New York Times, February 272006.

Gordon, Philip H., and Jeremy Shapiro. Allies at War: America, Europe, and the Crisis over Iraq. New York: McGraw-Hill, 2004.

Harnisch, Sebastian, and Hanns Maull. Germany as a Civilian Power?: The Foreign Policy of the Berlin Republic, Issues in German Politics. Manchester; New York: Manchester University Press, 2001.

Hassner, Pierre. The United States: The Empire of Force or the Force of Empire?, Chaillot Papers No. 54. Paris: Institute for Security Studies, European Union, 2002.

Hill, Christopher. "The Capability-Expectations Gap, or Conceptualizing Europe's International Role." Journal of Common Market Studies 31, no. 3 (1993): 305-28.

Hollis, Martin, and Steve Smith. Explaining and Understanding International Relations. Oxford, New York: Clarendon Press; Oxford University Press, 1990.

House, White. "The National Security Strategy of the United States of America." Washington, D.C.: White House, 2002.

Kagan, Robert. Paradise and Power: America and Europe in the New World Order. London, New York: Atlantic Books; Alfred A. Knopf, 2003. . "Power and Weakness." Policy Review 113 (2002).

Krauthammer, Charles. "The Unipolar Moment." Foreign Affairs 70 (1990/1991): 23-33.

LaFeber, Walter. The American Age: United States Foreign Policy at Home and Abroad since 1750. 2nd ed. 2 vols. New York: Norton, 1994. 
Mandelbaum, Michael. The Ideas That Conquered the World: Peace, Democracy, and Free Markets in the Twenty-First Century. 1st ed. New York: Public Affairs, 2002.

Mazzarr, Michael J. "George W. Bush, Idealist." International Affairs 79, no. 3 (2003): 503-22.

McCormick, James M. American Foreign Policy and Process. 4th ed. Belmont, CA: Thomson/Wadsworth, 2005.

McDougall, Walter A. Promised Land, Crusader State: The American Encounter with the World since 1776. Boston: Houghton Mifflin, 1997.

Mead, Walter Russell. Special Providence: American Foreign Policy and How It Changed the World. 1st ed. New York: Knopf, 2001.

Mendershausen, Horst. Civilian Power Europe. Santa Monica, Calif.: Rand Corp., 1975.

Meyer, Christoph O. "Convergence Towards a European Strategic Culture? A Constructivist Framework for Explaining Changing Norms." European Journal of International Relations 11, no. 4 (2005): 523-49.

Missiroli, Antonio "The European Union: Just a Regional Peacekeeper." European Foreign Affairs Review 8, no. 4 (2003).

Pond, Elizabeth. Friendly Fire: The near-Death of the Transatlantic Alliance, Eusa's-U.S.-Eu Relations Project Series. Pittsburgh, PA: European Union Studies Association, 2004.

Posen, Barry R., and Andrew Ross. "Competing Visions of U.S. Grand Strategy." International Security 21, no. 3 (winter 1996/97).

Rice, Condoleezza. "Promoting the National Interest." Foreign Affairs 79 (January/February 2000): 45-62.

Skiba, Alexander. "Die Nationale Sicherheitsstrategie Der USA Und Die Europäische Sicherheitsstrategie in Vergleich." In Wissenschaft \& Sicherheit: Beiträge zur Sicherheitspolitik - Sonderband: BSR- Arbeitskreise Sicherheitspolitik an Hochschulen, Sonderband 4/2004.

Telò, Mario. Europe, a Civilian Power? : European Union, Global Governance, World Order. Houndmills, Basingstoke, Hampshire ; New York: Palgrave Macmillan, 2006.

Tewes, Henning. Germany, Civilian Power, and the New Europe: Enlarging Nato and the European Union, New Perspectives in German Studies. Houndmills, Basingstoke, Hampshire ; New York: Palgrave, 2002.

Väyrynen, Raimo. "The European Union’s New Crisis Management Capability." Policy Briefing of the Joan B. Kroc Institute for Peace Studies, February 2000.

Walt, Stephen M. Taming American Power: The Global Response to U.S. Primacy. 1st ed. New York: Norton, 2005.

Waltz, Kenneth Neal. Man, the State, and War; a Theoretical Analysis. New York,: Columbia University Press, 1959.

White House. The National Security Strategy of the United States of America. Washington, D.C.: White House, 2002. . "The National Security Strategy of the United States of America." Washington, D.C.: White House, 2006.

Whitman, Richard. From Civilian Power to Superpower? : The International Identity of the European Union. Houndmills, Basingstoke, Hampshire, New York: Macmillan Press; St. Martin's Press, 1998.

Zakaria, Fareed. From Wealth to Power: The Unusual Origins of America's World Role, Princeton Studies in International History and Politics. Princeton, N.J.: Princeton University Press, 1998. 